\title{
OP-20 \\ Study of Geothermal Maronge, Sumbawa West Nusa Tenggara
}

\author{
Romi Aprianto \\ University of Samawa, Sumbawa Besar, rom.jenggot@gmail.com
}

\begin{abstract}
This study aims to determine the physical characteristics, analyze chemical properties, determine the type, estimate subsurface temperature, estimate geothermal gradient, and examine the use of hot springs in Maronge, Sumbawa, West Nusa Tenggara. Study was undertaken by collecting geological and geochemical data, followed by laboratory analysis. Study area for geothermal characteristization consists of four hot springs. The percentage of ions $\mathrm{HCO}^{3-}, \mathrm{Cl}^{-}$and $\mathrm{SO}^{2-}$ in hot water samples analyzed showed that the hot springs area of research is the chloride water type. Subsurface temperatures estimated using geothermometer $\mathrm{Na}-\mathrm{K}$ in the research area on the hot springs 1 to 4 are $210,68^{\circ} \mathrm{C}, 248,45^{\circ} \mathrm{C}, 243,28^{\circ} \mathrm{C}$ and $258,91^{\circ} \mathrm{C}$, and included in the high enthalpy which has a temperature limit $>225^{\circ} \mathrm{C}$. Geothermometer $\mathrm{Na}-\mathrm{K}$ - Mg showed that the hot springs in the study area are in partial equlibrium. It is further revealed that geothermal energy in the areas of research can be used as a power plant.
\end{abstract}

Keywords: hot spring, geothermal

\section{Background}

The potential of geothermal energy in Indonesia that reach $27 \mathrm{GWe}$ is closely associated with Indonesia's position in the world tectonic framework. Based on the appearance of geothermal surface per unit area, Indonesia is the in the fourth place of world rank. More than that, Indonesia is the world second largesttectonic framework in terms of high temperatures. Most of the geothermal energy used throughout the world is an energy extracted from the hydrothermal system, due to the utilization of hot-igneous system and conduction-dominated system requires high extraction technology. The hydrothermal system is closely related to the system of volcanism and the formation of a volcano on an active plate boundary zone where there is high heat flow (heat flow). Indonesia is at the confluence of three active plate which allows geothermal energy transferred from the depths to the surface through the fracture system. This strategic position puts Indonesia as the country with the richest geothermal energy scattered along the volcanic arc. So, most of the geothermal resources in Indonesia has a high eltalpi. (Wahyuningsih, 2005)

Geothermal is a renewable energy source and a clean and safe alternative energy. Most of the waste gas is carbon dioxide (CO2) and condensate water that has been taken can be reinjected into the reservoir to maintain the continuity of the reservoir. Based on the characteristics, geothermal energy can be used directly or indirectly. In order to optimize the utilization of geothermal energy, direct use can be developed concurrently with the development of geothermal energy for electricity.

Sumbawa island is on Sunda's orogen track volcanic (volcanic belt). Along this path there are many geothermal manifestations, which indicates the potential of geothermal energy at a particular depth. This potentcy will be able to generate electrical energy comes from geothermal energy if properly managed and planned. (Sundhoro et al, 2005).

Geothermal Maronge is one of three potential geothermal in West Nusa Tenggara beside Hu'u in Dompu with a 69 MWeenergy potentcy and Sembalun in Lombok with about 60 MWe - 70 MWe energy potency. Hu'u potential areas and Sembalun is already in the process of exploration, while areas of potential Maronge has not observed to determine the geothermal potential in detail yet. Based on this fact, researchers are interested in studying more about the potential of geothermal in the area Maronge. Purpose of this study is to determine the physical characteristics of the hot springs, the chemical properties of the hot springs, hot springs type, estimating subsurface temperature and geothermal gradient in order to find any benefits that can be obtained from the hot springs as a source of energy, agriculture and a tourist attraction site. 


\section{Literature Review}

Geothermal energy can be found in many places on this earth. However, geothermal area which has a high temperature that can be used for electrical energy is not available in many places.Geothermal energy is the natural heat energy from inside of the earth to the earth's surface that is transferred by conduction and convection. Generally, increased changes of temperature with depth in the earth's crust is about $30^{\circ} \mathrm{C} / \mathrm{km}$. If we assume the average temperature is $15^{\circ} \mathrm{C}$, the temperature of $3 \mathrm{~km}$ depth will reach $105^{\circ} \mathrm{C}$. However, the temperatur is unfavorable economically to be used as a source of geothermal energy.(Suparno, 2009)

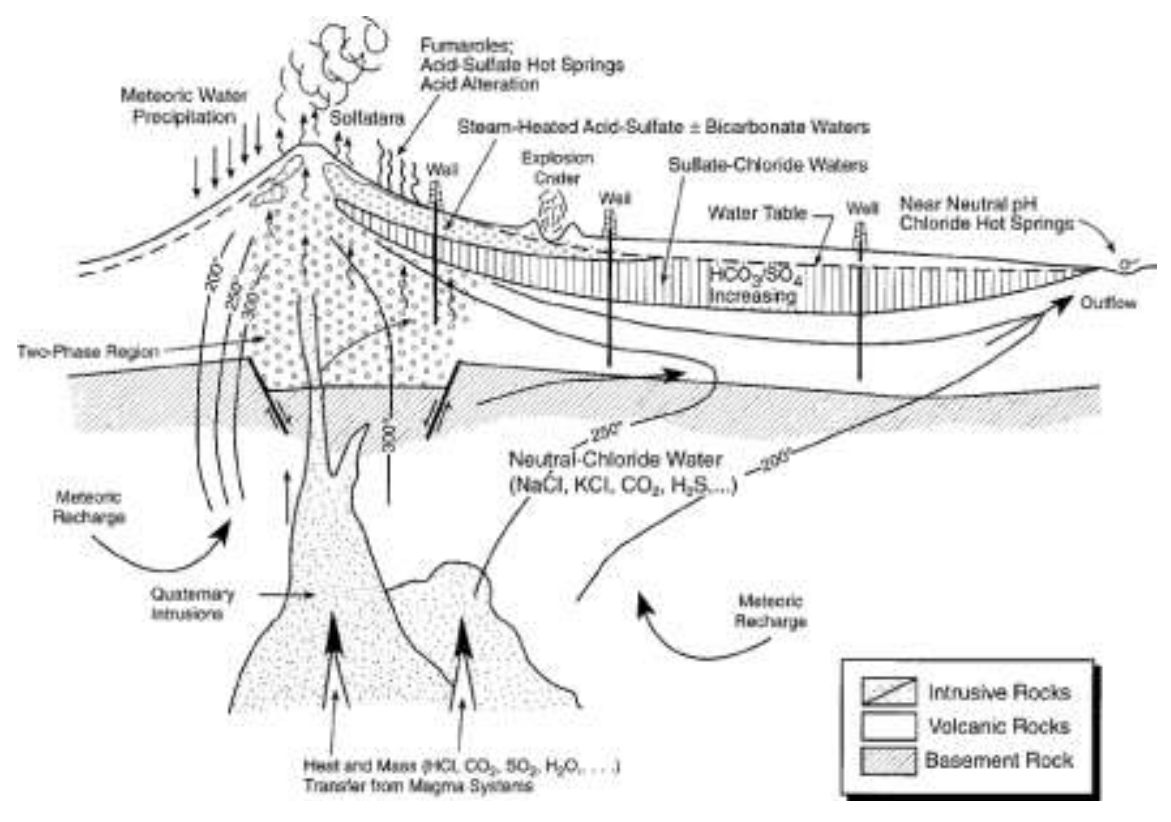

Figure 1. The conceptual model of the geothermal in young igneous rock system (Suparno, 2009)

Figure 1 displays a conceptual model of a geothermal system in the area of active andesitic stratovolcano. Andesite magma intrusion temperature usually ranges from 850 to $1050{ }^{\circ} \mathrm{C}$. Meteoric water down from the top to the bottom surface of the ground and heated by intrusive rocks causes the circulation of hot water. As the effect of onset of circulation, the hot water is rich of chemical elements such as $\mathrm{Cl}, \mathrm{F}, \mathrm{Br}, \mathrm{B}, \mathrm{SO} 4, \mathrm{HCO} 3$, silica, cations, and metal dissolved as a result of reaction with the source rock. Vapors contained in magma such as $\mathrm{H} 2 \mathrm{O}, \mathrm{CO} 2$, sulfur compounds, $\mathrm{HCl}, \mathrm{HF}, \mathrm{Hg}$, and As will be easily dislodged and flowed into the fluid. The fluid generally be "neutral-chloride" and tried to break up through the cracks of the rocks due to its density decreased. Mineral alteration and vein are formed in the reservoir rock. The hot fluid often rises up through the cracks until it reaches the boiling point of the depth level where the vapor phase that contains steam and non-condensible gases are formed. This gas comes to the surface as Fumarole.

\subsection{Geothermal Exploration Targets}

According DiPippo (2007), there are five objectives that must be achieved in the geothermal exploration program:

a. Determining the position of the hot rocks

b. Estimating the volume of the reservoir, the temperature of the fluid, and permeability formations.

c. Predicting the form of coming fluid (dry, liquid or two-phase mixture (vapor and liquid)).

d. Determining the chemical nature of the geothermal fluid

e. Estimating the potential of electrical energy that can be produced up to a minimum of 20 years. 
Almost all geothermal area has always been characterized by the presence of earth thermal manifestations. The presence of exact manifestations is caused by geothermal sources. However, the exact location does not found yet. In the spite of the fact, the surface of the soil which is usually hotter than the surroundings is enough to indicate the existence of geothermal resources underneath. Without the geothermal source, the soil surface will not become hot. Volume reservoir following reservoir rock permeability to note that the well's ability to produce or drain the fluid can be taken into account. If the volume is small and permeability is low, the production capacity will be low and it is probable that the well would has a very short lifespan.

According to Eliasson (2004), based on small large fluid temperature, geothermal reservoirs can be categorized into four, which are:

a. High temperatures, when the fluid temperature $>250{ }^{\circ} \mathrm{C}$

b. Medium temperature, when the fluid temperature range is between $150{ }^{\circ} \mathrm{C}-250{ }^{\circ} \mathrm{C}$

c. Low boiling temperature, if the fluid temperature range is between $100{ }^{\circ} \mathrm{C}-150{ }^{\circ} \mathrm{C}$

d. Low temperatures, when the fluid temperature range is between $50^{\circ} \mathrm{C}-10{ }^{\circ} \mathrm{C}$

Based on 4 categories, only reservoir medium temperature and high temperature reservoir that can stimulate investment geothermal energy power generation projects. Physical and chemical properties of reservoir fluids from the well drilling will determine the feasibility of geothermal projects.

\subsection{Hot Water Type}

The fluid type can be determined based on the content of chemical elements found in the most dominant hot spring and the physical processes that occur in it. There are some types of hot fluid (Huenges, 2010), such as Chloride, Sulphate, Bicarbonate, and Dilute Chloride Bicarbonate.

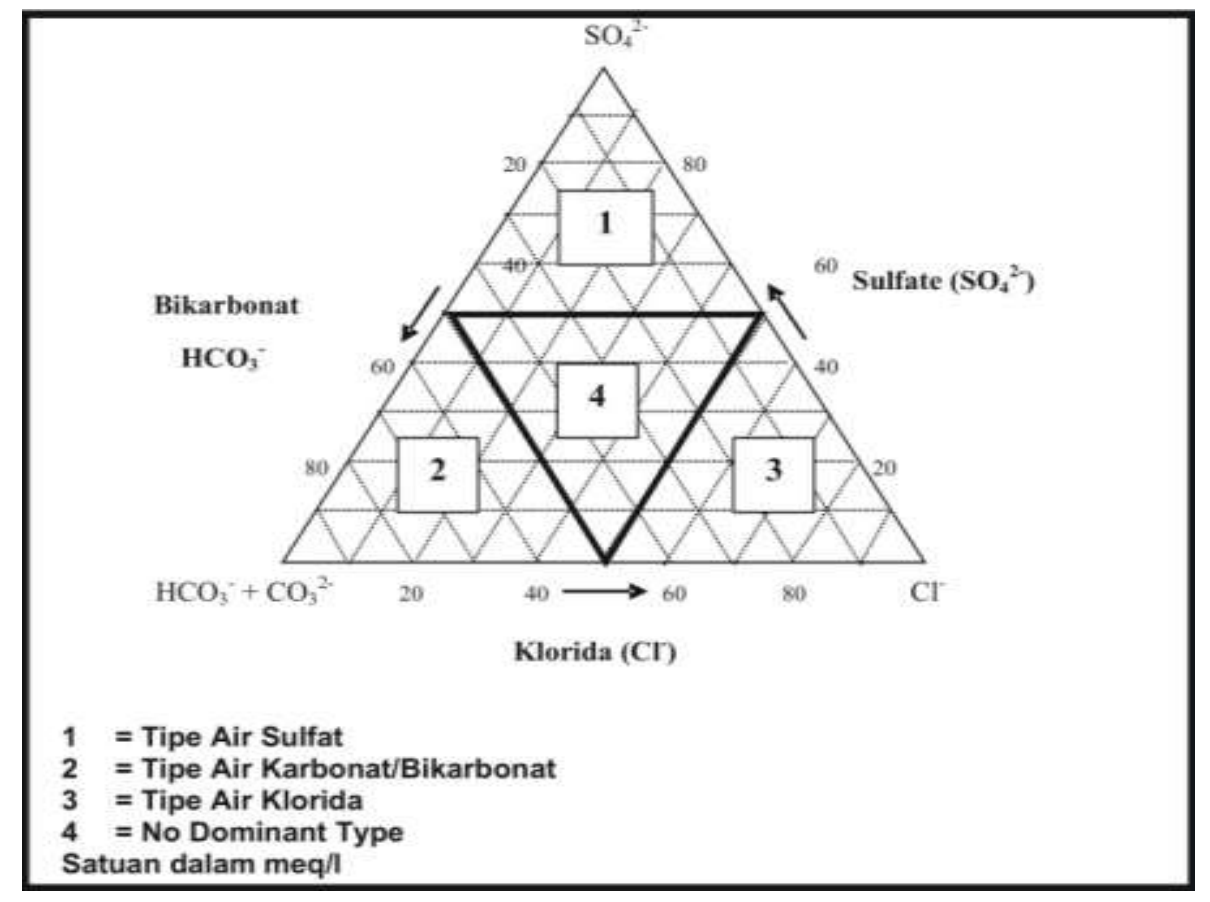

Figure 2. Trilinier diagram for the determination of the type of hot springs is based on the content of chloride ions, sulfate and bicarbonate. (Modified Giggenbach in Huenges, 2010)

\subsection{Temperature of Subsurface}

Subsurface temperature calculation can be performed using a system of equations geothermometer solution with parameter elements $\mathrm{Na}, \mathrm{K}$ and $\mathrm{Mg}$.

a. Geothemometer Na-K

Geothermometer with a ratio of $\mathrm{Na} / \mathrm{K}$ gives an indication of the high temperatures beneath the surface by seeing the elements sodium and potassium. The equation can be used to calculate the temperature of $\mathrm{Na}-\mathrm{K}$ comparison (Giggenbach, 1988) as follows: 


$$
\mathrm{T}^{\mathrm{o}} \mathrm{C}=\frac{1390}{[\log (N a / K)+1.750]^{-273}}
$$

b. Geothermometer Na-K-Mg

Formed as a result of exchange reactions with $\mathrm{Na}-\mathrm{K}-\mathrm{Mg}$ at a low temperature. Estimated subsurface temperature also affected the percentage of $\mathrm{Na} / 1000-\mathrm{K} / 100-\sqrt{M g}$ which can be calculated using the the value of each element ratio with total number of elements which are then plotted on Ternary diagram. (Huengen, 2010). Formula number of elements $\mathrm{Na}-\mathrm{K}-\mathrm{Mg}$ as follows:

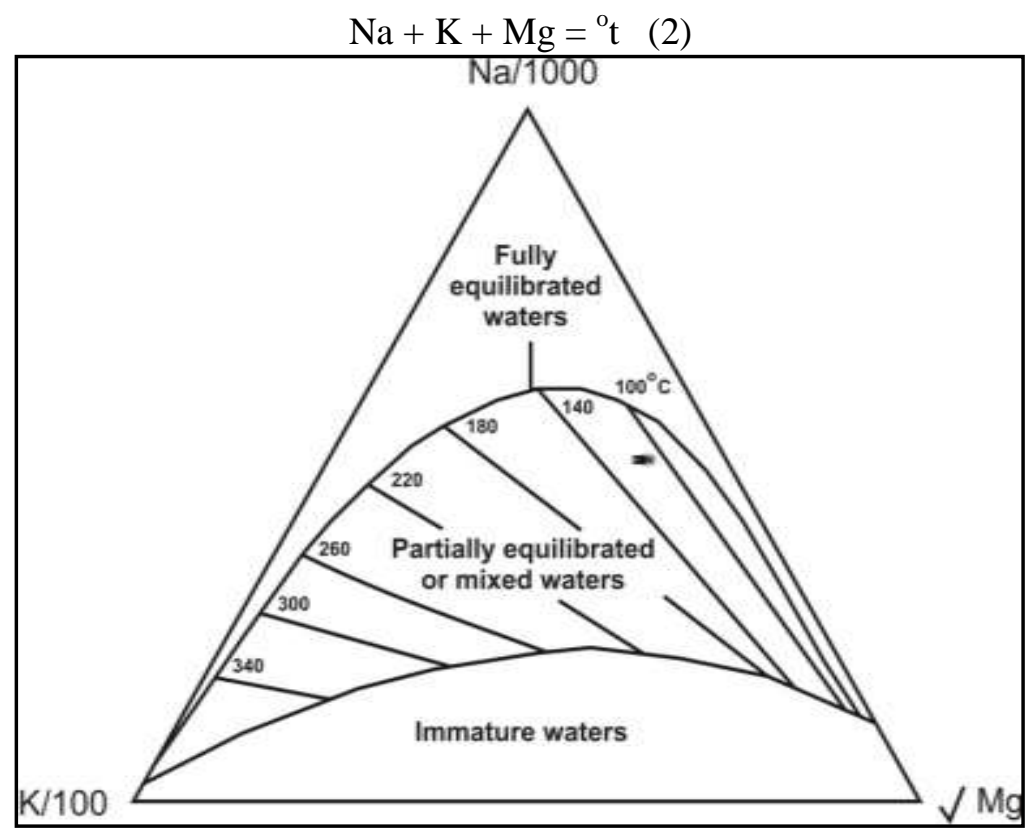

Figure 3. Ternary diagram for determining the temperature of subsurface (Giggenbach in Huenges, 2010)

\section{Methods}

\subsection{Stages of the Research}

The methods in this research are study of literature, field research, and laboratory analysis. This reseach consist of several stages:

\subsubsection{Preparation}

Each research activiy, always begins with preparation involves everything needed during the impelementation of the research. At this stage, things done are preparation of administration, tools and equipments, study of literature, and costplanning and schedule of activity.

\subsubsection{Field Research}

The activities at this stages are recording physical and chemical characteristics of the hotsprings data dan collecting rocks and hot water samples.

\subsubsection{Laboratory analysis}

Samples of hotsprings taken from the research location were analyzed in laboratory. This stage aims to determine the elements contained in the hot water.

\subsubsection{Data Processing}

After the elements contained in hot water are known, then analyzed the data to determine the physical characteristics of hot water, hot water chemical properties, the type of hot water, subsurface temperature, and depth of reservoir.

\subsubsection{Interpretation}


The final stage of this research is the interpretation of the data based on the result of field research on geological data, geochemical data and the processing results of laboratory analysis, and other supproting data related with the research.

\section{Result and Discussion}

4.1 Physical Characteristics of Hotsprings

Table 1.Phyisical and chemical characteristics of Hotsprings Maronge

\begin{tabular}{|c|c|c|c|c|c|}
\hline Hotsprings & Temperature (C) & Discharge & Colour & Taste & $\mathrm{pH}$ \\
\hline 1 & 42 & $1.5 \mathrm{~L} / 30$ second & Limpid & Insipid & 7,1 \\
\hline 2 & 41 & $1.5 \mathrm{~L} / 30$ second & Limpid & Insipid & 7,1 \\
\hline 3 & 33 & $1.5 \mathrm{~L} / 50$ second & Limpid & Insipid & 7,04 \\
\hline 4 & 33 & $1.5 \mathrm{~L} / 50$ second & Limpid & Insipid & 7,02 \\
\hline
\end{tabular}

\subsection{Geochemistry of Hotsprings}

Table2. Result of laboratory analysis of the hotsprings elements contained in research area

\begin{tabular}{|c|c|c|c|c|c|c|}
\hline \multirow{2}{*}{ No } & \multirow{2}{*}{ Parameter } & \multirow{2}{*}{ Unit } & \multicolumn{5}{|c|}{ Hotsprings } \\
\cline { 4 - 7 } & & & $\mathrm{I}$ & $\mathrm{II}$ & $\mathrm{III}$ & $\mathrm{IV}$ \\
\hline 1 & $\mathrm{Ca}$ (Calsium) & $\mathrm{mg} / \mathrm{L}$ & 4,7 & 5,15 & 4,6 & 6,7 \\
\hline 2 & $\mathrm{Mg}$ (Magnesium) & $\mathrm{mg} / \mathrm{L}$ & 0,1 & 0,18 & 0,12 & 0,12 \\
\hline 3 & $\mathrm{Na}$ (Natrium) & $\mathrm{mg} / \mathrm{L}$ & 149,6 & 147,4 & 155 & 145,6 \\
\hline 4 & $\mathrm{~K}$ (Kalium) & $\mathrm{mg} / \mathrm{L}$ & 11,25 & 17,9 & 17,7 & 19,95 \\
\hline 5 & $\mathrm{SO}_{4}$ (Sulfat) & $\mathrm{mg} / \mathrm{L}$ & 43,65 & 29,55 & 38,28 & 34,25 \\
\hline 6 & $\mathrm{Cl}_{\text {(Clorida })}$ & $\mathrm{mg} / \mathrm{L}$ & 381,1 & 129,57 & 198,17 & 175,3 \\
\hline 7 & $\mathrm{NH}_{3}$ (Amoniac) & $\mathrm{mg} / \mathrm{L}$ & 0.38 & 1,04 & 1,35 & 1,04 \\
\hline
\end{tabular}

\subsection{Type of Hotsprings}

Determination of the type of hot water based on geochemical analysis performed using diagram trinilier classification, which is based on the relative content of anion chloride, sulfate, and bicarbonate. The amount of the content of these ions is expressed in units of $\mathrm{mEq} / \mathrm{L}$ (miliequivalent per liter). So it must be converted from ppm to $\mathrm{mEq} / \mathrm{L}$.

$\mathrm{Meq} / \mathrm{L}=\mathrm{ppm} / \mathrm{Weight}$ of Equivalent

Weigh of Equivalent $=$ MrCompund $/$ Valence Hotspring 1

Table 3 Calculation of chloride ion, sulphate, and bicarbonatelevel from $\mathrm{ppm}$ to $\mathrm{mEq} / \mathrm{L}$ at hotspring 1

\begin{tabular}{|c|c|c|c|c|c|c|}
\hline \multirow{2}{*}{ Coumpund } & \multicolumn{3}{|c|}{$\mathrm{HCO}_{3}$} & \multicolumn{2}{c|}{$\mathrm{SO}_{4}$} & $\mathrm{Cl}$ \\
\cline { 2 - 7 } & $\mathrm{H}$ & $\mathrm{C}$ & $\mathrm{O}$ & $\mathrm{S}$ & $\mathrm{O}$ & $\mathrm{Cl}$ \\
\hline Amount of Atoms & 1 & 1 & 3 & 1 & 4 & 1 \\
\hline Mass of Atoms (Ar) & 1 & 12 & 16 & 32 & 16 & 35.5 \\
\hline Amount of Atom Mass & 1 & 12 & 48 & 32 & 64 & 35.5 \\
\hline Mr & \multicolumn{3}{|c|}{61} & \multicolumn{2}{|c|}{96} & 35.5 \\
\hline Valence of each Coumpound & \multicolumn{3}{|c|}{1} & \multicolumn{2}{|c|}{2} & 1 \\
\hline Weight of Equivalent (WE) & \multicolumn{3}{|c|}{61} & 43.65 & 35.5 \\
\hline Level (ppm) & \multicolumn{5}{|c|}{0.909375} & 10.73521 \\
\hline Meq/L & \multicolumn{5}{|c|}{0} & 0.809458627 \\
\hline Level Amount (Meq/L) & \multicolumn{5}{|c|}{} \\
\hline Percentase/Coumpound & \multicolumn{5}{|c|}{0} \\
\hline
\end{tabular}


Proceedings International Conference on Mathematics, Sciences and Education, University of Mataram 2015 Lombok Island, Indonesia, November 4-5, 2015

Hotspring 2

Table 4. Calculation of chloride ion, sulphate, and bicarbonate level from $\mathrm{ppm}$ to $\mathrm{mEq} / \mathrm{L}$ at hotspring 2

\begin{tabular}{|c|c|c|c|c|c|c|}
\hline \multirow{2}{*}{ Coumpund } & \multicolumn{3}{|c|}{$\mathrm{HCO}_{3}$} & \multicolumn{2}{|c|}{$\mathrm{SO}_{4}$} & $\mathrm{Cl}$ \\
\hline & $\mathrm{H}$ & $\mathrm{C}$ & $\mathrm{O}$ & $\mathrm{S}$ & $\mathrm{O}$ & $\mathrm{Cl}$ \\
\hline Amount of Atoms & 1 & 1 & 3 & 1 & 4 & 1 \\
\hline Mass of Atoms (Ar) & 1 & 12 & 16 & 32 & 16 & 35.5 \\
\hline Amount of Atom Mass & 1 & 12 & 48 & 32 & 64 & 35.5 \\
\hline $\mathrm{Mr}$ & \multicolumn{3}{|c|}{61} & \multicolumn{2}{|c|}{96} & 35.5 \\
\hline Valence of each Coumpound & \multicolumn{3}{|c|}{1} & \multicolumn{2}{|c|}{2} & 1 \\
\hline Weight of Equivalent (WE) & \multicolumn{3}{|c|}{61} & \multicolumn{2}{|c|}{48} & 35.5 \\
\hline Level $(\mathrm{ppm})$ & \multicolumn{3}{|c|}{0} & \multicolumn{2}{|c|}{29.55} & 129.57 \\
\hline $\mathrm{Meq} / \mathrm{L}$ & \multicolumn{3}{|c|}{0} & \multicolumn{2}{|c|}{0.615625} & 3.649859 \\
\hline Level Amount (Meq/L) & \multicolumn{6}{|c|}{4.265484155} \\
\hline Percentase/Coumpund & \multicolumn{3}{|c|}{0} & \multicolumn{2}{|c|}{14.43271098} & 85.56729 \\
\hline
\end{tabular}

Hotspring 3

Table 5. Calculation chloride ion, sulphate, and bicarbonate level from $\mathrm{ppm}$ to $\mathrm{mEq} / \mathrm{L}$ at hotspring 3

\begin{tabular}{|c|c|c|c|c|c|c|}
\hline \multirow[t]{2}{*}{ Coumpund } & \multicolumn{3}{|c|}{$\mathrm{HCO}_{3}$} & \multicolumn{2}{|c|}{$\mathrm{SO}_{4}$} & \multirow{2}{*}{$\begin{array}{l}\mathrm{Cl} \\
\mathrm{Cl}\end{array}$} \\
\hline & $\mathrm{H}$ & $\mathrm{C}$ & $\mathrm{O}$ & $\mathrm{S}$ & $\mathrm{O}$ & \\
\hline Amount of Atoms & 1 & 1 & 3 & 1 & 4 & 1 \\
\hline Mass of Atoms (Ar) & 1 & 12 & 16 & 32 & 16 & 35.5 \\
\hline Amount of Atom Mass & 1 & 12 & 48 & 32 & 64 & 35.5 \\
\hline $\mathrm{Mr}$ & \multicolumn{3}{|c|}{61} & \multicolumn{2}{|c|}{96} & 35.5 \\
\hline Valence of each Coumpound & \multicolumn{3}{|c|}{1} & \multicolumn{2}{|c|}{2} & 1 \\
\hline Weight of Equivalent (WE) & \multicolumn{3}{|c|}{61} & \multicolumn{2}{|c|}{48} & 35.5 \\
\hline Level (ppm) & \multicolumn{3}{|c|}{0} & \multicolumn{2}{|c|}{38.28} & 198.17 \\
\hline Meq/L & \multicolumn{3}{|c|}{0} & \multicolumn{2}{|c|}{0.7975} & 5.582254 \\
\hline Level Amount (Meq/L) & \multicolumn{6}{|c|}{6.379753521} \\
\hline Percentase/Coumpund & \multicolumn{3}{|c|}{0} & \multicolumn{2}{|c|}{12.50048293} & 87.49952 \\
\hline
\end{tabular}

Hotspring 4

Table 6. Calculation of chloride ion, sulphate, and bicarbonate level from ppm to $\mathrm{mEq} / \mathrm{L}$ at hotspring 4

\begin{tabular}{|c|c|c|c|c|c|c|}
\hline \multirow[t]{2}{*}{ Coumpund } & \multicolumn{3}{|c|}{$\mathrm{HCO}_{3}$} & \multicolumn{2}{|c|}{$\mathrm{SO}_{4}$} & \multirow{2}{*}{$\begin{array}{l}\mathrm{Cl} \\
\mathrm{Cl}\end{array}$} \\
\hline & $\mathrm{H}$ & $\mathrm{C}$ & $\mathrm{O}$ & $\mathrm{S}$ & $\mathrm{O}$ & \\
\hline Amount of Atoms & 1 & 1 & 3 & 1 & 4 & 1 \\
\hline Mass of Atoms (Ar) & 1 & 12 & 16 & 32 & 16 & 35.5 \\
\hline Amount of Atom Mass & 1 & 12 & 48 & 32 & 64 & 35.5 \\
\hline $\mathrm{Mr}$ & \multicolumn{3}{|c|}{61} & \multicolumn{2}{|c|}{96} & 35.5 \\
\hline Valence of each Coumpound & \multicolumn{3}{|c|}{1} & \multicolumn{2}{|c|}{2} & 1 \\
\hline Weight of Equivalent (WE) & \multicolumn{3}{|c|}{61} & \multicolumn{2}{|c|}{48} & 35.5 \\
\hline Level (ppm) & \multicolumn{3}{|c|}{0} & \multicolumn{2}{|c|}{34.25} & 175.3 \\
\hline $\mathrm{Meq} / \mathrm{L}$ & \multicolumn{3}{|c|}{0} & \multicolumn{2}{|c|}{0.713541667} & 4.938028 \\
\hline Level Amount (Meq/L) & \multicolumn{6}{|c|}{5.651569836} \\
\hline Percentase/Coumpund & \multicolumn{3}{|c|}{0} & \multicolumn{2}{|c|}{12.62554808} & 87.37445 \\
\hline
\end{tabular}


Proceedings International Conference on Mathematics, Sciences and Education, University of Mataram 2015 Lombok Island, Indonesia, November 4-5, 2015

Table 7 Result of percentase calculation of chloride ion, sulphate, and bicarbonate

\begin{tabular}{|c|l|c|c|c|c|}
\hline \multirow{2}{*}{ No } & \multirow{2}{*}{ Parameter } & \multicolumn{3}{|c|}{ Hotspring } & \\
\cline { 3 - 6 } & & 1 & 2 & 3 & 4 \\
\hline 1 & $\% \mathrm{Cl}$ & 92.19057698 & 85.56728902 & 87.49951707 & 87.37445192 \\
\hline 2 & $\% \mathrm{SO}_{4}$ & 7.809423015 & 14.43271098 & 12.50048293 & 12.62554808 \\
\hline 3 & $\% \mathrm{HCO}_{3}$ & 0 & 0 & 0 & 0 \\
\hline \multicolumn{2}{|l}{ Hotspring Type } & Chloride & Chloride & Chloride & Chloride \\
\hline
\end{tabular}

Based on percentage value of ion in sample of hot water which has analyzed the content of chemical elements, especially content of anions bicarbonate, chloride, and sulphate, it is known that the four hotspringsMaronge including the type chloride. It is characterized by high content of chloride ions compared with bicarbonate and sulphate.

\subsection{Temperature of Subsurface}

\subsubsection{Geothermometer Na-K}

Hotspring 1

$$
\begin{aligned}
& \mathrm{t}^{\mathrm{o}} \mathrm{C}=\frac{1390}{[\log (N a / K)+1.750]}-273 \\
& \mathrm{t}^{\mathrm{o}} \mathrm{C}=\left[\frac{1390}{[\log (149,6 / 11,25) \mid+1.750]^{-273}}\right. \\
& \mathrm{t}^{\mathrm{o}} \mathrm{C}=\frac{1390}{[1.12+1.750]^{-273}} \\
& \mathrm{t}^{\mathrm{o}} \mathrm{C}=210,68^{\circ} \mathrm{C}
\end{aligned}
$$

Hotspring 2

$$
\begin{aligned}
\mathrm{t}^{\circ} \mathrm{C} & =\frac{1390}{[\log (N a / K)+1.750]}-273 \\
\mathrm{t}^{\mathrm{o}} \mathrm{C} & =[\log (83.47 / 1.44) \mid+1.750]^{-273} \\
\mathrm{t}^{\circ} \mathrm{C} & =\frac{1390}{[0,92+1.750]^{-273}} \\
\mathrm{t}^{\circ} \mathrm{C} & =248,45^{\circ} \mathrm{C}
\end{aligned}
$$

Hotspring 3

$$
\begin{aligned}
\mathrm{t}^{\mathrm{o}} \mathrm{C} & =\frac{1390}{[\log (N a / K)+1.750]^{-273}} \\
\mathrm{t}^{\mathrm{o}} \mathrm{C} & =\frac{1390}{[\log (255 / 17,7) \mid+1.750]^{-273}} \\
\mathrm{t}^{\mathrm{o}} \mathrm{C} & =\frac{1390}{[0,94+1.750]}-273
\end{aligned}
$$


Proceedings International Conference on Mathematics, Sciences and Education, University of Mataram 2015 Lombok Island, Indonesia, November 4-5, 2015

$$
\mathrm{t}^{\circ} \mathrm{C}=243,28^{\circ} \mathrm{C}
$$

Hotspring 4

$$
\begin{aligned}
& \mathrm{t}^{\circ} \mathrm{C}=\frac{1390}{[\log (\mathrm{Na} / \mathrm{K})+1.750]^{-273}} \\
& \mathrm{t}^{\mathrm{o}} \mathrm{C}=\frac{1390}{[\log (145,6 / 19,95) \mid+1.750]^{-273}} \\
& \mathrm{t}^{\circ} \mathrm{C}=\frac{1390}{[0,86+1.750]^{-273}} \\
& \mathrm{t}^{\circ} \mathrm{C}=258,91{ }^{\circ} \mathrm{C}
\end{aligned}
$$

Tabel 8. Temperature of subsurface at research area

\begin{tabular}{|l|c|c|c|c|}
\hline \multirow{2}{*}{ Subsurface temperature $\left({ }^{\circ} \mathrm{C}\right)$} & Hotspring I & Hotspring II & Hotspring III & Hotspring IV \\
\cline { 2 - 5 } & 210.68 & 248,45 & 243,28 & 258,91 \\
\hline
\end{tabular}

\subsubsection{Geothermometer Na-K-Ca}

Table 9. Temperature of subsurface based on contentof Na-K-Ca

\begin{tabular}{|c|c|c|c|c|c|c|r|}
\hline $\begin{array}{c}\text { Hot } \\
\text { Springs }\end{array}$ & $\frac{N a}{1000}$ & $\frac{K}{100}$ & $\sqrt{M g}$ & $\frac{N a}{1000}+\frac{K}{100}+\sqrt{M g}$ & $\% \mathrm{Na}$ & $\% \mathrm{~K}$ & $\%(\sqrt{M g})$ \\
\hline 1 & 0,1496 & 0,1125 & 0,316228 & 0,578327766 & 25,868 & 19,45 & 54,68 \\
\hline 2 & 0,1474 & 0,179 & 0,424264 & 0,750664069 & 19,636 & 23,85 & 56,52 \\
\hline 3 & 0,155 & 0,177 & 0,34641 & 0,678410162 & 22,848 & 26,09 & 51,06 \\
\hline 4 & 0,1456 & 0,1995 & 0,34641 & 0,691510162 & 21,055 & 28,85 & 50,09 \\
\hline
\end{tabular}

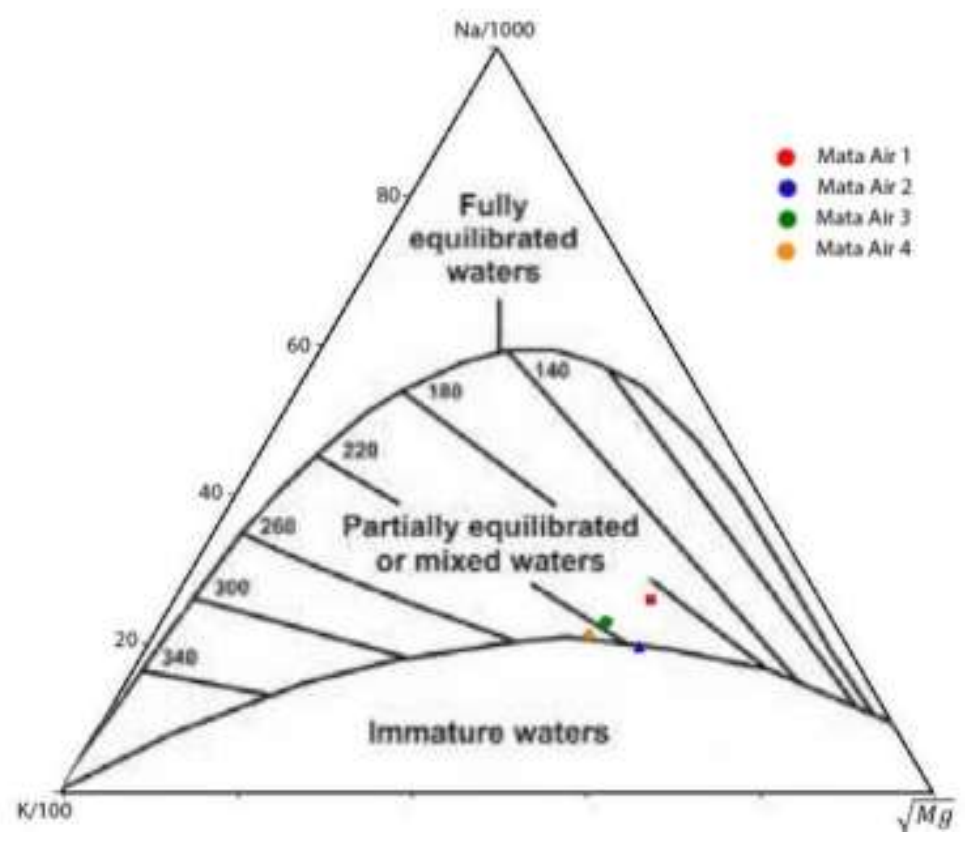

Figure 4.Ternary Diagram for determining subsurface temperature

Estimated temperatures below the surface is calculated using geothermometer $\mathrm{Na}-\mathrm{K}$. hot spring 1 has a below the surface temperature of $210,68^{\circ} \mathrm{C}$, hot spring 2 has a below the surface 
temperature of $248,45^{\circ} \mathrm{C}$, hot spring 3 has a below the surface temperature of $243,28^{\circ} \mathrm{C}$, and hotspring 4 has a below the surface temperature of $258,91^{\circ} \mathrm{C}$ (Table 8).

Based on the results of plotting of the level of chemical elements contained in the ternary $\mathrm{Na}-\mathrm{K}-\mathrm{Mg}$ diagram, (Figure 4) it can be seen that the hot springs in the study area included in the partial equilibrium. There has been interaction between the rocks with hot fluid before to the surface, so that the temperature of the hot water is classified as a high-temperature geothermal source. Springs that appear on the surface has begun to be affected by the water on the surface so it has a different temperature.

\subsection{Geothermal Reservoir}

Reservoir conditions in the study area can be determined based on the content of the elements of the hot area of research. Based on the relative content of $\mathrm{Cl}, \mathrm{HCO}_{3}$, and $\mathrm{SO}_{4}{ }^{2-}$, hot water in the study area contains relatively very high $\mathrm{Cl}$ compared to the $\mathrm{HCO}_{3}$, and $\mathrm{SO}_{4}{ }^{2-}$ compounds. This shows that the hot water in Maronge is originating from volcanic activity.

$\mathrm{Na}-\mathrm{K}$ geothermometer calculation is performed to determine the temperature of the geothermal reservoir below the surface. This Geothermometer is used to heat water that has undergone interaction with the surrounding rock for a long time. This Geothermometer, unlike geothermometer silica, are not affected by the mixing or loss steam. Based on the distribution of hot springs and reservoir temperature indicated by geothermometer dissolved elements, it can be concluded that the geothermal reservoir in the study area that supplies the hot springI 1 , hot spring II, hot spring III, and hot spring IV have a temperature of about $210.68^{\circ} \mathrm{C}, 248.45^{\circ} \mathrm{C}, 243.28^{\circ} \mathrm{C}$ and $258.91^{\circ} \mathrm{C}$. Further north, the higher temperature the reservoir is. While getting to the south of the study area, the temperature of the hot water reservoir gets smaller. Hot springs Maronge are type of chloride which is a direct output vertically (upflow) of the water reservoir. Reservoirs of hot springs in the study area is included in the high enthalpy, which has a temperature limit $>225^{\circ} \mathrm{C}$, so it is included in the high-temperature geothermal.

\subsection{Gradient of Geothermal}

The depth of the magma chamber in the research area can be calculated by the ratio of the surface temperature with the temperature of the subsurface from geothermometer analysis. If thestudy area is assumed as a volcanic-magmatic pathway, the depth will increaseby 100 meters;andthe temperature will be increase by about $2,5^{\circ} \mathrm{C}$ up to $3^{\circ} \mathrm{C}$. Table 10 indicates the approximate depth of the reservoir hot area of research.

Table 10 Estimated depth of the Maronge geothermal reservoir

\begin{tabular}{|c|c|c|c|}
\hline Hot Springs & Surface Temperature $\left({ }^{\circ} \mathrm{C}\right)$ & Subsurface Temperature $(\circ \mathrm{C})$ & Depth of Reservoir $(\mathrm{km})$ \\
\hline 1 & 42 & 210.68 & 6.7472 \\
\hline 2 & 41 & 248.45 & 8.298 \\
\hline 3 & 33 & 243.28 & 8.4112 \\
\hline 4 & 33 & 258.91 & 9.0364 \\
\hline
\end{tabular}

\subsection{Utilization of Geothermal at Research Area}

In optimization of geothermal resources, utilization of geothermal energy for direct use can be developed along with the development of geothermal energy as an alternative to electricity. Utilization of hot springs can be determined by knowing the physical characteristics, types of hot springs, the depths of the reservoir, perform chemical analysis of the value of the $\mathrm{pH}$ and temperature of the subsurface.

Based on the analysis of field data and geochemical data, the temperature of the hot springs at the surface is between $33^{\circ} \mathrm{C}-42^{\circ} \mathrm{C}$ at $\mathrm{pH} 7$. Geothermometer calculations indicating that the temperature of the bottom surface of the reservoir is $210,68^{\circ} \mathrm{C}-258,91^{\circ} \mathrm{C}$. It is included to the type of high-enthalpy reservoirs since the temperature $>225^{\circ} \mathrm{C}$ and a high-temperature geothermal sources. Therefore, the study area is very suitable to be developed as a source of electrical energy. 


\section{Conclusion}

Based on the research results and observations,the conclusions are : hot springs area of research is the chloride water type. Subsurface temperatures estimated using geothermometer $\mathrm{Na}$ $\mathrm{K}$ in the research area on the hot springs 1 to 4 are $210,68^{\circ} \mathrm{C}, 248,45^{\circ} \mathrm{C}, 243,28^{\circ} \mathrm{C}$ and $258,91^{\circ} \mathrm{C}$, and included in the high enthalpy which has a temperature limit $>225^{\circ} \mathrm{C}$. Geothermometer $\mathrm{Na}-\mathrm{K}$ - Mg showed that the hot springs in the study area are in partial equlibrium. Utilization of geothermal energy in the areas of research can be used as a power plant.

\section{References}

DiPippo, R,. 2007. Geothermal Power Plants, 2nd Ed. McGraw-Hill.

Eliasson, ET., Power generation from high-enthalpy geothermal resources, GHC Bulletin, June2004, pp 26-34.

Huenges, E. 2010. Geothermal Energy System. Weinhem: Wiley-VCH.

Sundhoro, H et al. 2005. Geothermal Integrated Survey (Geology, Geochemistry and Geophysics) Regional Hu'u, Dompu, West Nusa Tenggara).Kolokium Hasil Lapangan - DIM.

Suparno, S. 2009. Geothermal Energy (A Present from the heart of the earth). FMIPA UI.

Wahyuningsih, R. 2005. Potential and Mining Working Area Geothermal in Indonesia. Kolokium Hasil Lapangan - DIM. 